Research article

urn:Isid:zoobank.org:pub:8FC18411-850C-499C-90C4-5DBFB500137B

\title{
A new deepwater species of Calliopiidae, Halirages helgae (Crustacea, Amphipoda), with a synoptic table to Halirages species from the northeast Atlantic
}

\author{
Halldis RINGVOLD ${ }^{1}$ \& Anne Helene Solberg TANDBERG ${ }^{2}$ \\ ${ }^{1}$ Sea Snack Norway, Løbergsveien, 5055 Bergen, Norway. \\ Corresponding author: halldisr@gmail.com \\ ${ }^{2}$ Institute of Marine Research, P.O. Box 1870 Nordnes, NO-5817 Bergen, Norway. \\ Email: annehelene.tandberg@imr.no \\ ${ }^{1}$ urn:Isid:zoobank.org:author:2578D662-A47D-41B0-84EB-421D77BDE005 \\ ${ }^{2}$ urn:1sid:zoobank.org:author:26BB8830-FA36-4F87-B3DD-0C28C7F0C504
}

\begin{abstract}
Halirages helgae sp. nov. is recorded from the shelf slopes of the Norwegian Sea at depths of 1000 to $2600 \mathrm{~m}$ in the Arctic cold water masses. A total of 50 specimens were found at five stations. The species differs from other known species in the genus Halirages Boeck, 1871 by the bilobed posterior margin of pereonite 7. A synoptic table to the northeast Atlantic species of Halirages is provided.
\end{abstract}

Keywords. Amphipoda, Calliopiidae, MAREANO, northeast Atlantic, Norwegian Sea

Ringvold H. \& Tandberg A.H.S. 2014. A new deepwater species of Calliopiidae, Halirages helgae (Crustacea, Amphipoda), with a synoptic table to Halirages species from the northeast Atlantic. European Journal of Taxonomy 98: 1-13. http://dx.doi.org/10.5852/ejt.2014.98

\section{Introduction}

MAREANO, a programme to develop a Marine Areal database for Norwegian waters, was initiated in 2005 and conducts physical, biological, and environmental mapping of the sea bottom within Norwegian waters (Fig. 1). The programme procures information for an ecosystem-based management of Norway's coastal and offshore regions. MAREANO (www.mareano.no) is an ongoing program, and one of the aims is to increase the knowledge of marine benthic species. A new calliopiid species has been found at five of the stations; we suggest placing the new species in the genus Halirages.

Calliopiidae is a large cosmopolitan family that includes 79 species in 26 genera worldwide (Barnard \& Karaman 1991). Arctic and subarctic regions are particularly rich in species of Calliopiidae (Barnard \& Karaman 1991; Weisshappel 2001). In the northeast Atlantic and Norwegian Arctic 12 genera have been recorded in Calliopiidae, with three Haliragoides species (Sars 1883; Gurjanova 1951; d'Udekem d'Acoz 2007) and eight Halirages species (Sars 1858, 1877; Ohlin 1895; Kamenskaya 1980; Stephensen 1931; Gurjanova 1946; d'Udekem d'Acoz 2012). 


\section{Material and methods}

Altogether 17 cruises have been undertaken from 2005 through 2013 in the MAREANO program; they included 1013 video stations, of which 252 were physically sampled using a van Veen grab; 246 of these stations also included sampling with a beam trawl and 201 with a Rothlisberg-Piercy (RP) sledge. The survey area up until 2013 has covered 130,000 km²; it has included the shelf and slope off the coast of Nordland and Troms counties, parts of the SE Barents Sea and the banks off mid-Norway. The material for this study was collected in 2008 and 2010. All samples were processed on board to facilitate further handling and sorting. RP samples were decanted before being sieved at $4 \mathrm{~mm}, 1 \mathrm{~mm}$, and $0.5 \mathrm{~mm}$. Only the decanted fractions were identified for this study. The samples were fixed in $4 \%$ borax-buffered formalin and transferred to $75 \%$ ethanol after sorting in the lab. All material has been deposited in the Bergen University Museum, Norway (ZMBN). Permanent slides were made with Faure's medium, and drawings were made with a tablet (Wacom Bamboo CTH-470) and Adobe Illustrator (Version CS 5.1) as shown by Coleman (2003). Length measurements are from tip of rostrum to tip of telson.

\section{Results}

Class Malacostraca Latreille, 1802

Order Amphipoda Latreille, 1816

Superfamily Eusiroidea Stebbing, 1888

Family Calliopiidae G.O. Sars, 1893

\section{Halirages Boeck, 1871}

A total of 50 specimens were found at five stations. The specimens are placed in the genus Halirages for the following reasons: labrum rounded apically and acute dorsally, labium with small inner lobes, length of mandible palp article 3 about half that of article 2. Coxal plates small, coxa 1 not expanded distally.

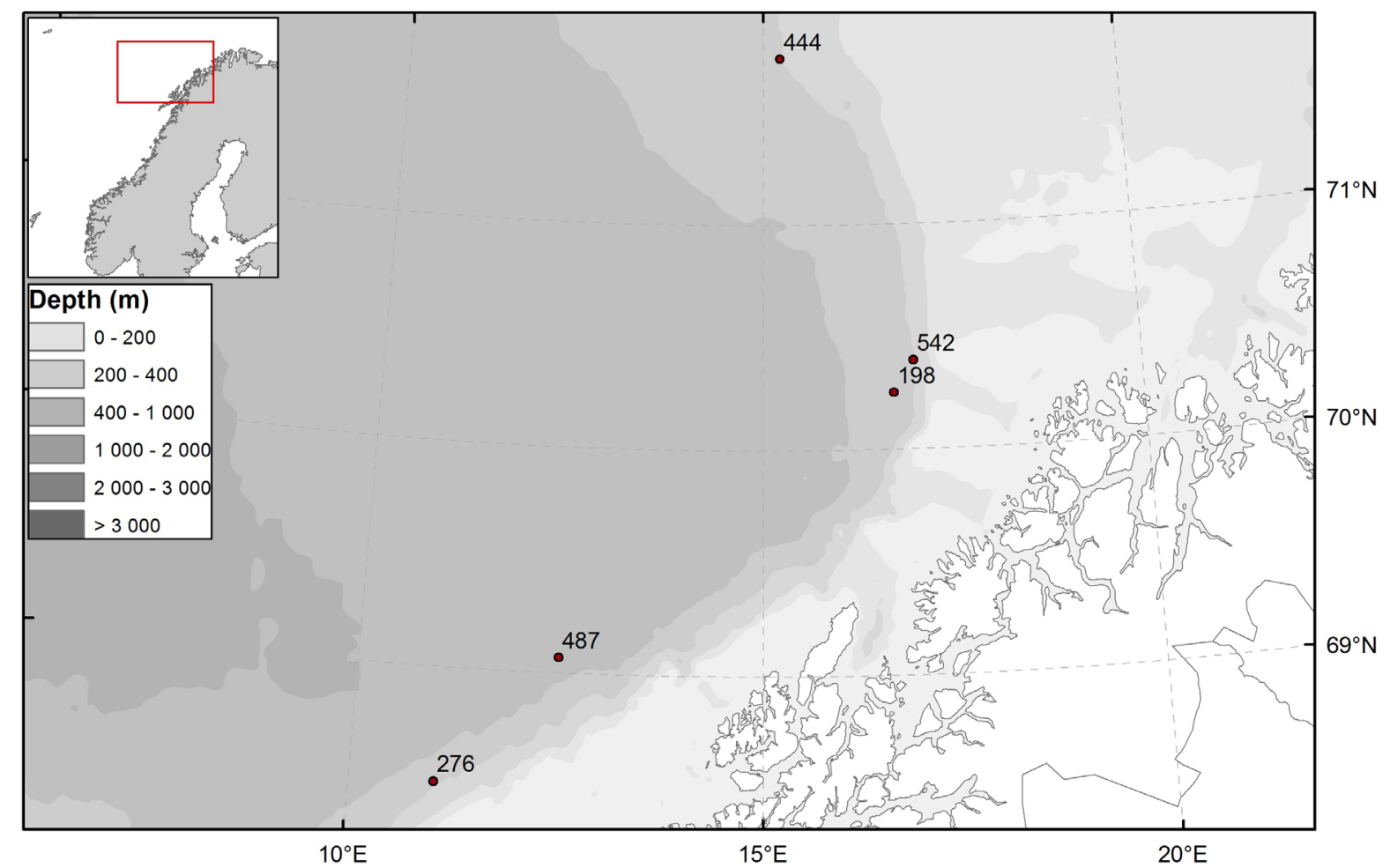

Fig. 1. Part of the MAREANO survey area off northern Norway, with indications of stations where Halirages helgae sp. nov. was found. 
Gnathopods 1 and 2 subequal, propodi subrectangular, ischium of pereopod 7 with a small posterodistal process, second epimeral plate with small tooth on posteroventral corner, third epimeral plate smooth. Pereonite 7 with bilobed posterior margin. The uropods of all examined specimens were badly damaged, and only peduncles and proximal parts of rami were available for study.

Halirages helgae sp. nov.

urn:lsid:zoobank.org:act:94170470-2502-4808-A77B-248EEACD8EF6

Figs 2-7

\section{Diagnosis}

Head with short rostrum, anteroventral corner with small projecting tooth. Eyes present, but very small, whitish in alcohol. Article 3 of mandible palp about half the length of article 2. Pereonite 7, and in large animals $(>11 \mathrm{~mm})$ also pereonite 6 and pleonite 2, with weakly bilobed posterior margin. Length of dactylus on first and second gnathopod about half that of propodus palm. Carpus longer than propodus. Epimeral plate 2 with small tooth posteroventrally, and epimeral plate 3 with posterior corner rounded. Uropods 1 and 2 biramous, with strong setae. Telson entire, longer than wide, acute.

\section{Etymology}

The species is named in memory of Helga Ringvold, for encouraging her children in their future endeavours.

\section{Material examined}

\section{Holotype}

NORWAY: $+10.5 \mathrm{~mm}$ long, R/V G.O. Sars, cruise 11408, st. 276-030A, Nordland, slope of Moskenesgrunnen, $68^{\circ} 28.86^{\prime} \mathrm{N}, 10^{\circ} 55.81^{\prime} \mathrm{E}, 1292 \mathrm{~m}$, mud, $-0,87^{\circ} \mathrm{C}$, salinity $34.92 \%$, RP sledge, leg. H. Ringvold (ZMBN 90142).

\section{Paratypes}

NORWAY: 4 +, , 9-13 mm long, R/V G.O. Sars, cruise 10408, st. 198-003A, Troms, slope of Mulegga, $70^{\circ} 14.67^{\prime} \mathrm{N}, 16^{\circ} 44.52^{\prime} \mathrm{E}, 1532 \mathrm{~m}$, cobbles, $-0.78^{\circ} \mathrm{C}$, salinity $34.92 \%$ o (ZMBN $88021-88024$ ). A total of 31 slides has been made of the holotype and paratypes.

\section{Additional material}

NORWAY: 1 q, $10 \mathrm{~mm}$ long, R/V G.O. Sars, cruise 11109, st. 487-157, Nordland, W of Lofoten, $69^{\circ} 04.13^{\prime} \mathrm{N}, 12^{\circ} 26.91^{\prime} \mathrm{E}, 2609 \mathrm{~m}$, mud, clay and gravel, $-0.82^{\circ} \mathrm{C}$, salinity $34.89 \%$; 35 우 (6 with eggs; 3 juveniles), 3-13 mm long, R/V G.O. Sars, cruise 10408, st. 198-003A, Troms, slope of Mulegga, $70^{\circ} 14.67^{\prime} \mathrm{N}, 16^{\circ} 44.52^{\prime} \mathrm{E}, 1532 \mathrm{~m}$, cobbles, $-0.78^{\circ} \mathrm{C}$, salinity $34.92 \%$; 6 웅, $5-11 \mathrm{~mm}$ long, R/V G.O. Sars, cruise 11109, st. 444-148, Troms, slope of Eggagrunnen, $71^{\circ} 44.4^{\prime} \mathrm{N}, 15^{\circ} 14.22^{\prime} \mathrm{E}, 997 \mathrm{~m}$, cobbles, $-0.73^{\circ} \mathrm{C}$, salinity $34.88 \%$; 3 9 $9,7-11 \mathrm{~mm}, \mathrm{R} / \mathrm{V}$ G.O. Sars, cruise 11010 , st. 542-357, Troms, Vesthola, Egga, $70^{\circ} 23.69^{\prime} \mathrm{N}, 16^{\circ} 58.86^{\prime} \mathrm{E}, 1189 \mathrm{~m}$, gravelly sand and sandy mud, $-0.66^{\circ} \mathrm{C}$, salinity $34.9 \%$.

\section{Description}

Body. Up to $13 \mathrm{~mm}$ long. Pereonites 1-5 smooth, dorsal posterior margin of pereonite 7 slightly bilobed (Fig. 2B) (also on pereonite 6 and pleonite 2 on some large specimens greater than $11 \mathrm{~mm}$ long). Head (Fig. 3A). Rostrum short; corner of cephalic lobe with small projecting tooth; eye small (can be difficult to see in preserved specimens), reniform.

Antenna 1 (Fig. 3B). Flagellum broken in all examined specimens. Peduncle of article 1 longer than article 2, article 3 about $1 / 3$ length of article 2, which has a posterodistal process. Eight articles remaining in flagellum, with one short seta on three of them. 
Antenna 2 (Fig. 3C). Flagellum broken in all examined specimens. Article 5 longer than articles 3-4 combined, articles $4-5$ with short spines, article 5 with a posterodistal process.

LABRUM (Fig. 3D). Rounded apically and acute dorsally.

LABIUM (Fig. 3E). With small inner lobes.

MANDIBLE (Fig. 4D). Incisor process with 4 blunt teeth; lacinia mobilis with 4 teeth on left molar; molar triturative, with ridged grinding surface and with row of lateral spines; palp 3-articulate, with elongate article 2, articles 2-3 with elongate setae on ventral margin. Article 3 short.

Maxilla 1 (Fig. 4A). Inner plate with 9 plumose setae; outer plate with 11 spines of which 5-6 are bifurcate; palp 2-articulate and well developed, article 1 expanded distally, article 2 tapering and with 2 rows of 5-6 spines, one row apically and the other slightly lower. Left article 2 with long marginal

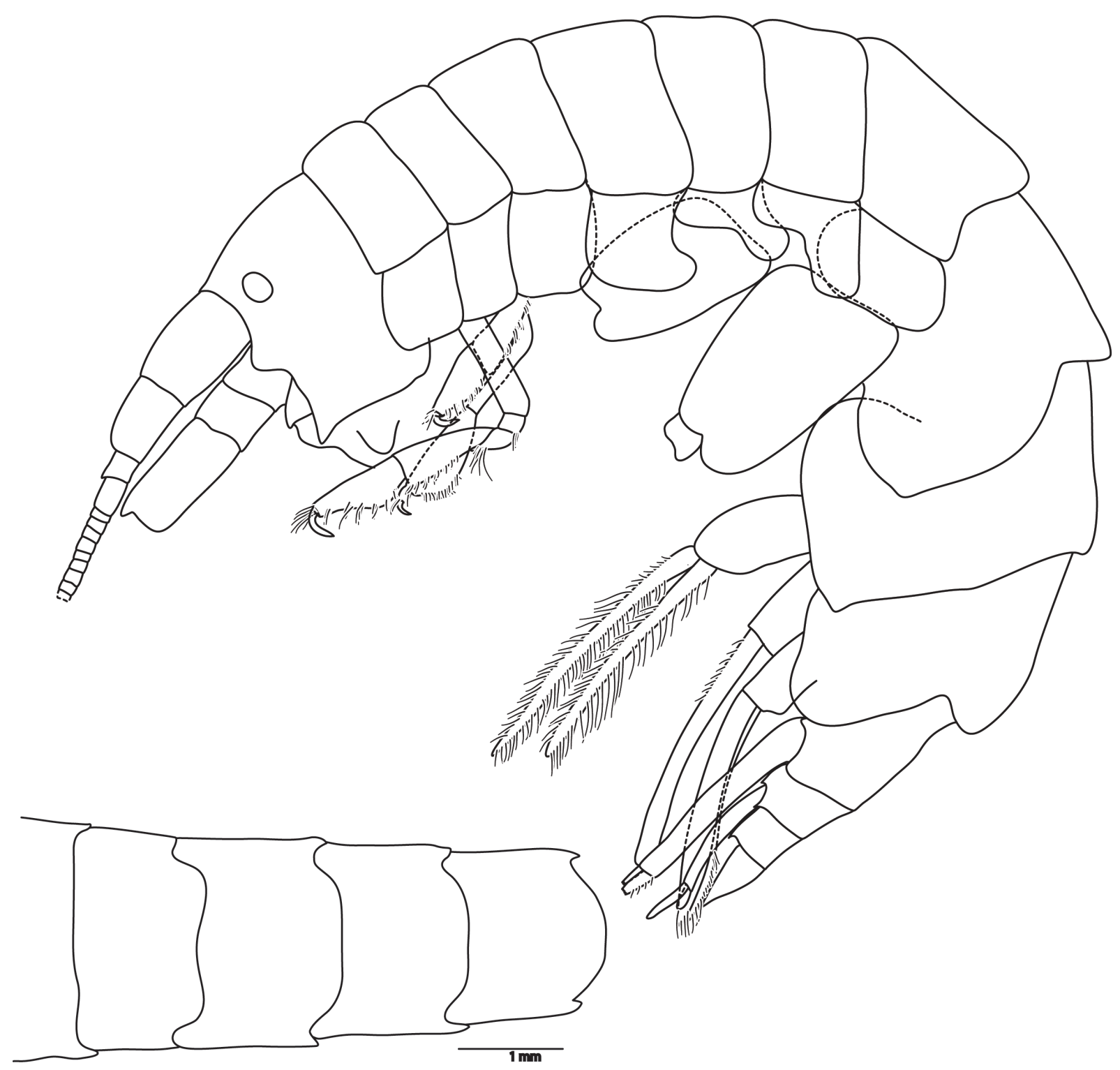

Fig. 2. Halirages helgae sp. nov. A. Holotype,, , $10 \mathrm{~mm}$ long. B. Dorsal side, showing bilobed posterior margin of pereonite 7; paratype $1, \circ, 10 \mathrm{~mm}$ long. 

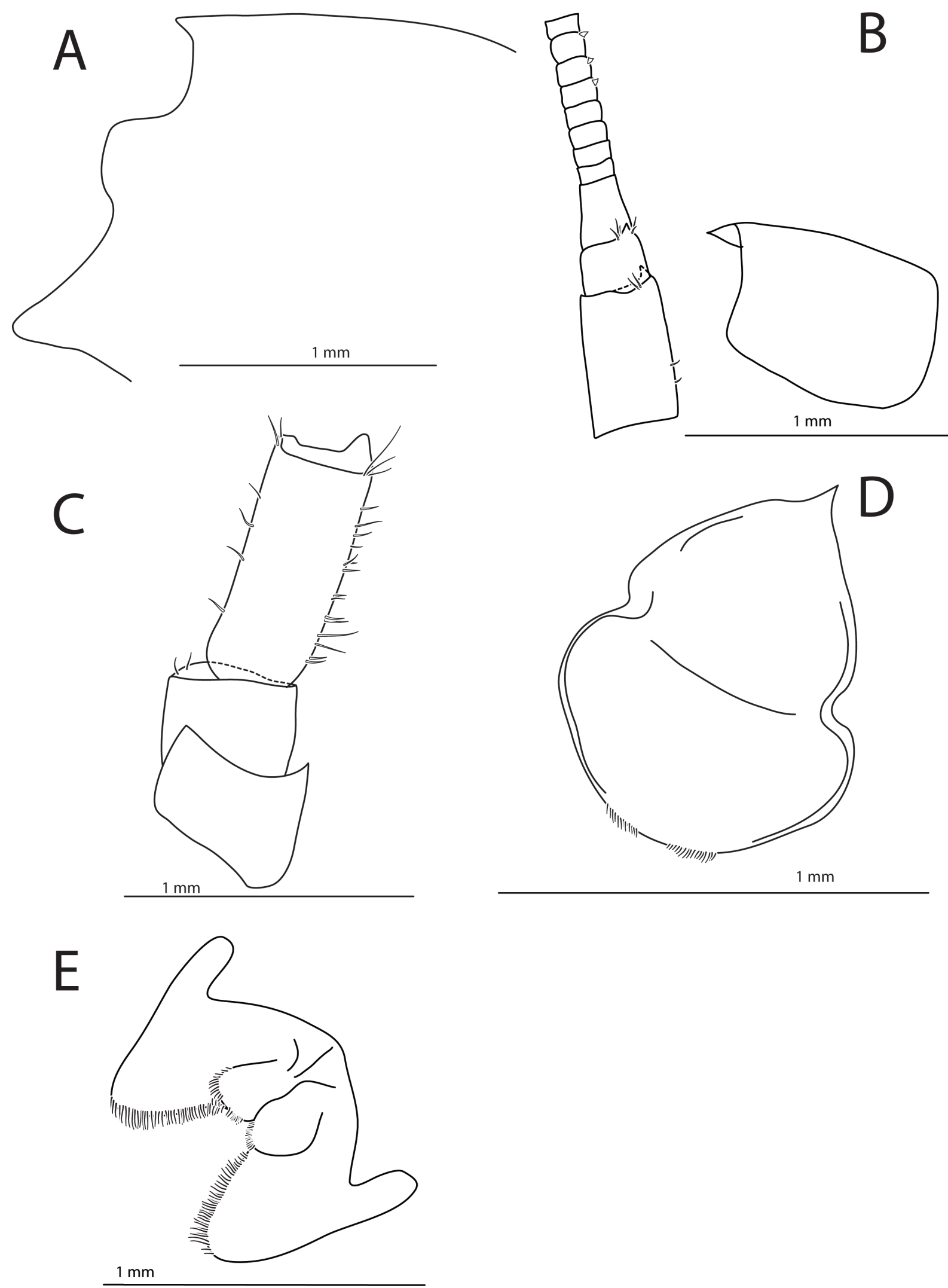

Fig. 3. Halirages helgae sp. nov., holotype, $\uparrow, 10 \mathrm{~mm}$ long. A. Head. B. Antenna 1. C. Antenna 2. D. Upper lip. E. Lower lip. 
spines and margino-facial setae, right article 2 with a row of 6-7 stout, conical marginal spines with margino-facial row of setae.

MaXILLa 2 (Fig. 4B). Outer plate longer than inner plate, both plates with long setae apically. Upper and inner plate with posterior setae, on inner plate the setae also reach posterodistal area.

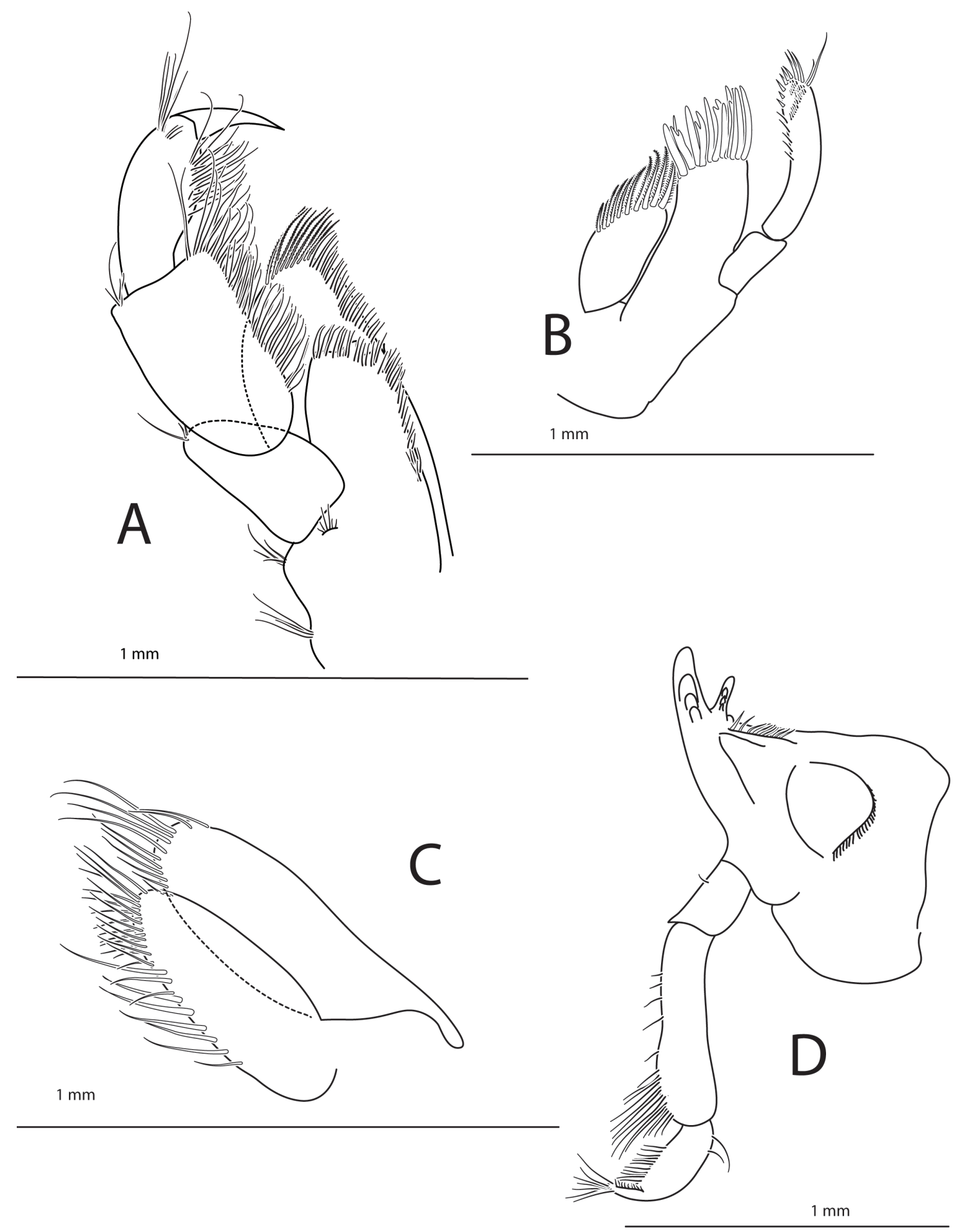

Fig. 4. Halirages helgae sp. nov., holotype,,, $10 \mathrm{~mm}$ long. A. Maxilliped. B. Maxilla 1. C. Maxilla 2. D. Mandible. 
MAXILLIPED (Fig. 4C). Broad and covered with numerous setae; inner plate short with short setae apically and on inner margins, three apical teeth; outer plate slender with long setae apically and on inner margins; palp articles 2-3 elongate, article 2 longest; article 3 with long setae apically and on inner margins; dactylus stout, about half length of article 3.

GNATHOPODS 1 AND 2 (Fig. 5A and 5B). Quite similar in shape: both coxae sub-quadrate and smooth; bases rectangular with a few short setae; ischia narrow; meri longer than wide, with group of setae apically; propodi shorter than carpi, subovate, carpi subtriangular with rows of setae along posterior margin, propodi subtriangular. Gnathopod 1 carpus length / width ratio 3.0, of propodus 1.9. Gnathopod 2 carpus length / width ratio 2.7 , of propodus 1.9; carpus setae along hind margins and palms, with

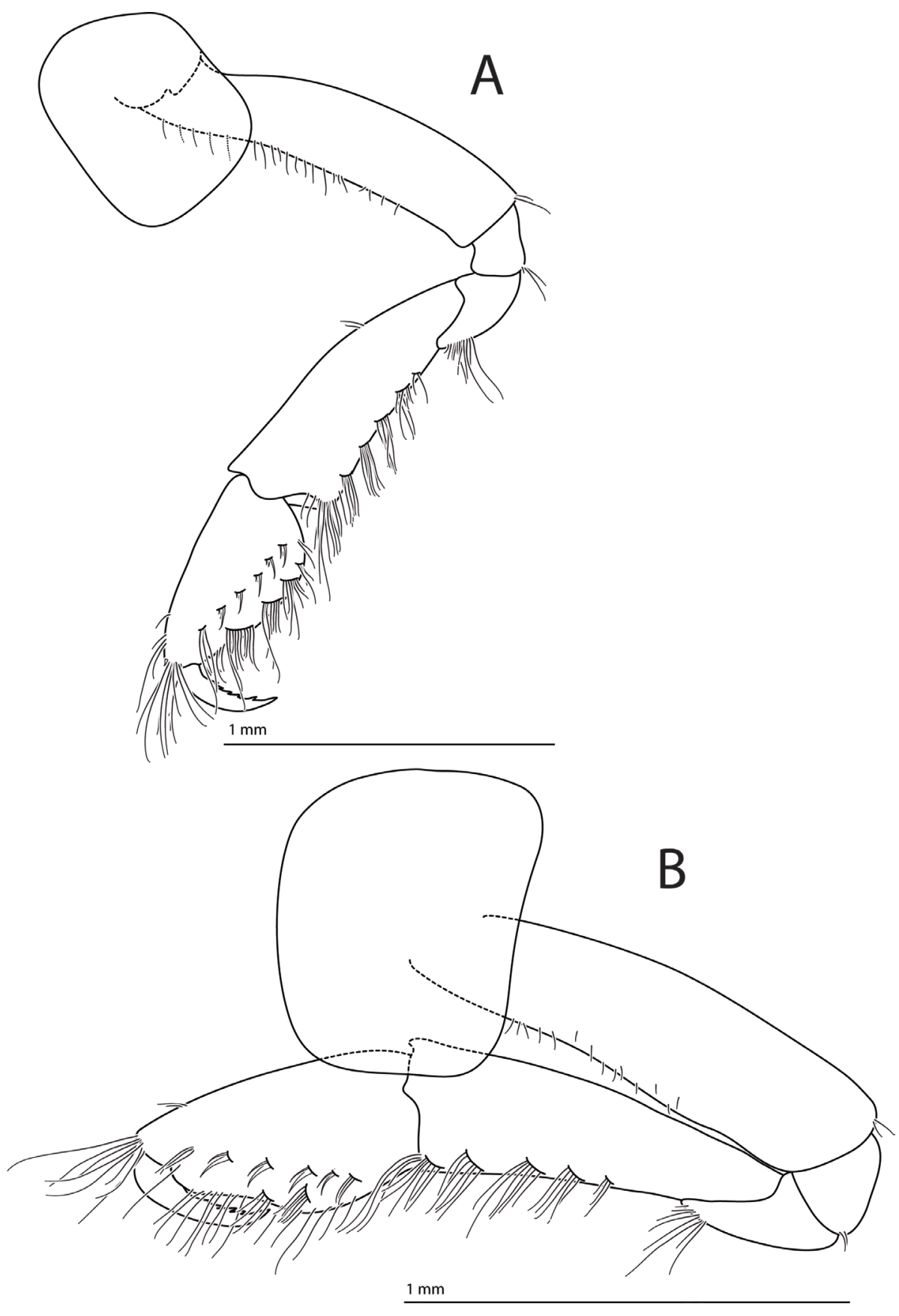

Fig. 5. Halirages helgae sp. nov., holotype,, , $10 \mathrm{~mm}$ long. A. Gnathopod 1. B. Gnathopod 2. 
groups of setae along inner face, palm of gnathopods 1 and 2 similar and slightly excavate; dactyli on both gnathopods about half length of propodus palm, with dentate inner margin.

Pereopods 3-7 (Fig. 6A-E). Coxa 3 sub-quadrate and smooth, coxa 4 posteriorly excavate, coxae 5 and 6 longer than wide, coxa 7 elliptic and smallest of all coxae; bases of pereopods 5-7 broad and
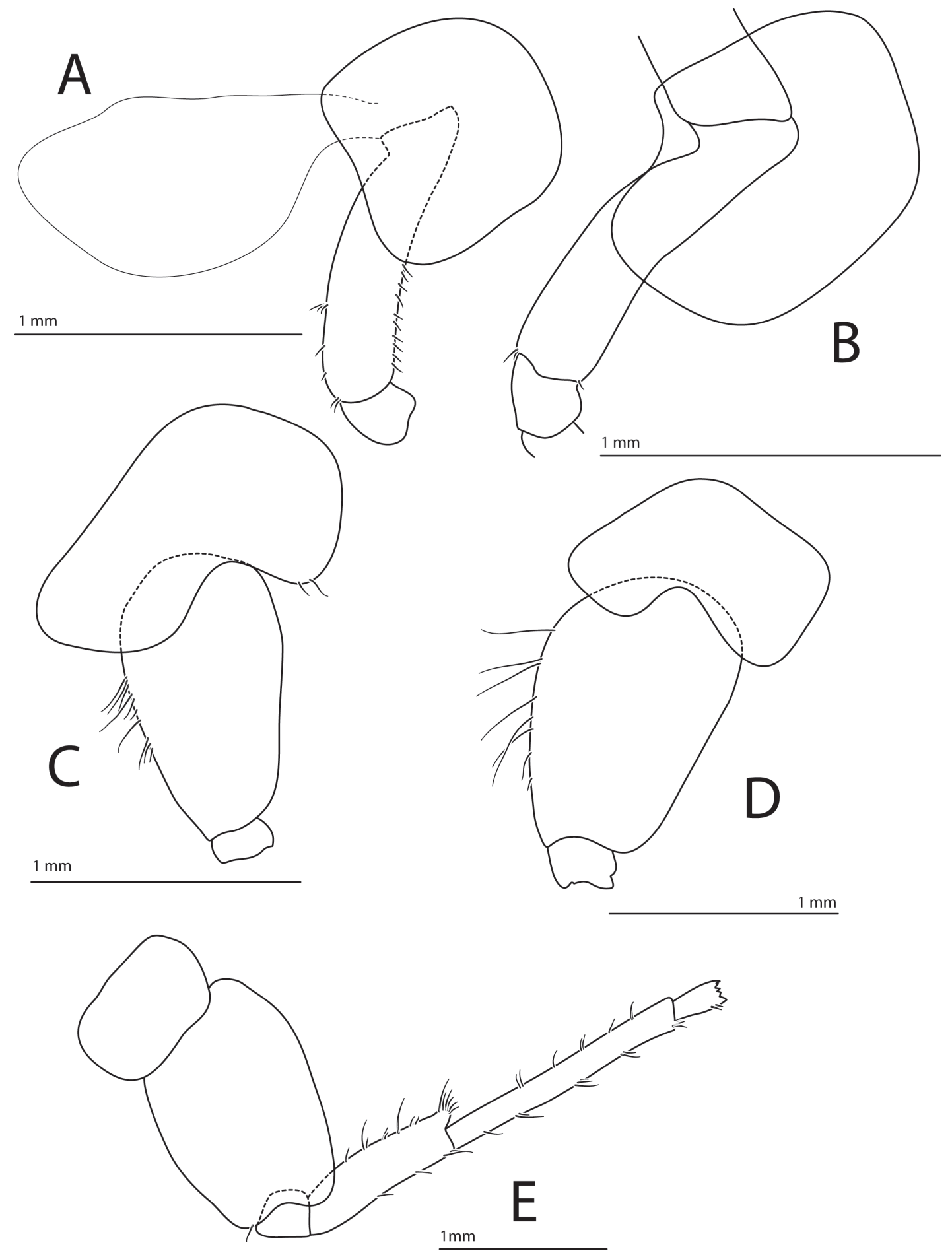

Fig. 6. Halirages helgae sp. nov. A-D. Holotype,,$+ 10 \mathrm{~mm}$ long. A. Pereiopod 3. B. Pereiopod 4. C. Pereiopod 5. D. Pereiopod 6. - E. Paratype 2,, , 9 mm long. Pereiopod 7. 
posteriorly smooth. Articles of pereopods 4-7 missing on all specimens except paratype 2, which has one pereopod 7 that includes carpus; ischium short and square-shaped, merus with setae along both margins and long setae apically, carpus with setae on both margins, 7 times as long as wide, and 1.5 times as long as merus.

UROPODS 1 AND 2 (Fig. 7A and 7B). With spines on both margins of peduncles and rami. Rami damaged on all specimens.

UROPOD 3. Missing on all specimens.

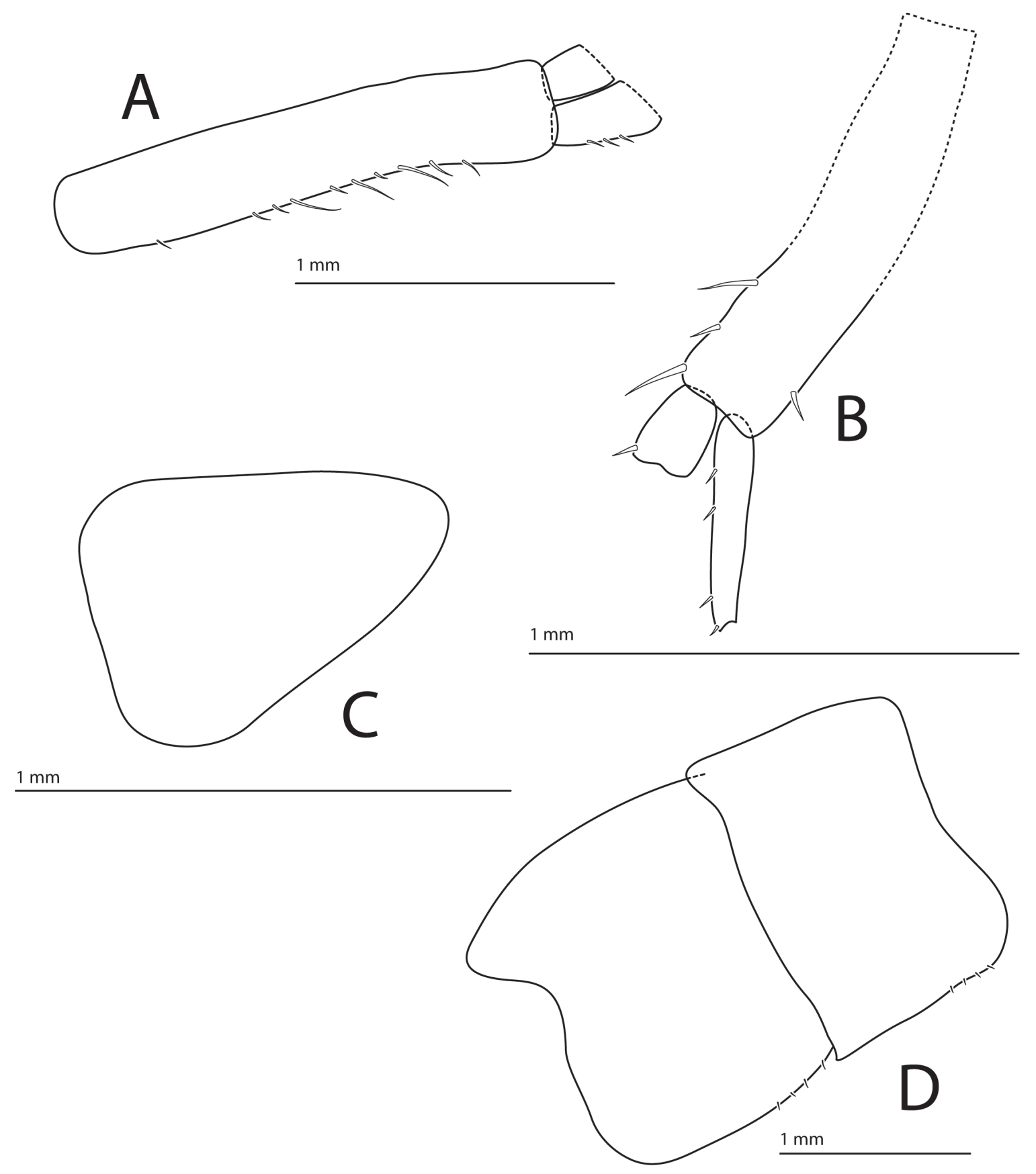

Fig. 7. Halirages helgae sp. nov., holotype, $q, 10 \mathrm{~mm}$ long. A. Uropod 1. B. Uropod 2. C. Telson. D. Epimeron 2-3. 
Telson. Entire, longer than wide, triangular with blunt tip (Fig. 7C).

EPIMERAL PLATES. Epimeral plate 1 posteriorly rounded, posteroventral corner obtusely angular; epimeral plate 2 with small, posteroventral tooth; epimeral plate 3 with posteroventral corner rounded and with posterior border smooth and nearly straight (Fig. 7D).

COLOUR PATTERn. Colour of live specimens unrecorded.

\section{Distribution}

This species has only been found in the northeast Atlantic, off northern Norway. It has been recorded at some of MAREANO's deepest stations, from 997 to 2,609 m, and only in cold water masses (NSAIW, Norwegian Sea Arctic Intermediate Water) (Buhl-Mortensen et al. 2012), with mud as the dominant sediment.

\section{Discussion}

The entire calliopiid family is in need of revision. Both Stephensen (1931) and d'Udekem d'Acoz (2012) stated that the differences between Halirages and Apherusa are blurred. It can also be difficult to separate Halirages and Haliragoides morphologically (Sars 1895; Stephensen 1931; M. Thurston pers. comm.), but differences regarding cephalic lobes, antennal calceoli and the rami on uropod 3 have been suggested as characters useful for separating them. The head of Halirages helgae sp. nov. has a small projecting tooth anterodistally. The damaged antennae show no calceoli (only females have been found, and according to Stephensen (1931) and d'Udekem d'Acoz (2012) calceoli are probably present in all males in Halirages but not always in the females).

The species fits more or less the characters of the genus Halirages, and in the present confused systematic situation, it is preferable to assign it to this genus.

As many Calliopiidae, Halirages helgae sp. nov. is a brittle species. The specimens differ somewhat in size $(3-13 \mathrm{~mm})$ and probably include both juveniles and adults. The species seems to be morphologically closest to H. mixtus Stephensen, 1931 and H. gorbunovi Gurjanova, 1946, based on the absence of dorsal spines. One should, however, take into consideration that thorough descriptions are lacking for both species, and that $H$. gorbunovi is only known from its two mutilated type specimens, which actually look similar to H. quadridentatus G.O. Sars, 1877 (d'Udekem d'Acoz 2012). The examined specimens of $H$. helgae sp. nov. have a bilobed posterior margin on pereonite 7 and differ from $H$. gorbunovi in the fact that coxae 1 and 2 are not ventrally serrate, and that $H$. helgae sp. nov. has eyes. The telson on $H$. mixtus is emarginate and the posterior margin of epimeron 3 serrate, whereas the telson of $H$. helgae sp. nov. is triangular with a blunt tip, and the posterior margin of the third epimeron is smooth.

Apart from H. mixtus and H. gorbunovi, six other species within Halirages are described from the northeast Atlantic: H. fulvocinctus (M. Sars, 1858), H. quadridentatus, H. nilssoni Ohlin, 1895, H. caecus Kamenskaya, 1980, H. cainae d'Udekem d'Acoz, 2012, and H. stappersi d'Udekem d'Acoz, 2012. Halirages helgae sp. nov. differs from all these species by the bilobed posterior margin of pereonite 7 . The posteroventral corner of epimeral plate 2 is toothed and that of epimeral plate 3 rounded. See the synoptic table (Table 1) for a more detailed compilation of how the characters are distributed.

It can be debated whether the species Haliragoides abyssi Gurjanova, 1951 (we have not been able to study this as no specimens were available for study) should be transferred to the genus Halirages due to the dissimilarity it shows with the two other Haliragoides species, described by Sars (1883) and d'Udekem d'Acoz (2007). The head of H. abyssi does not have a large, sub-cephalic process as in the other Haliragoides species. This species also seems to lack eyes. If H. abyssi is transferred to Halirages, 


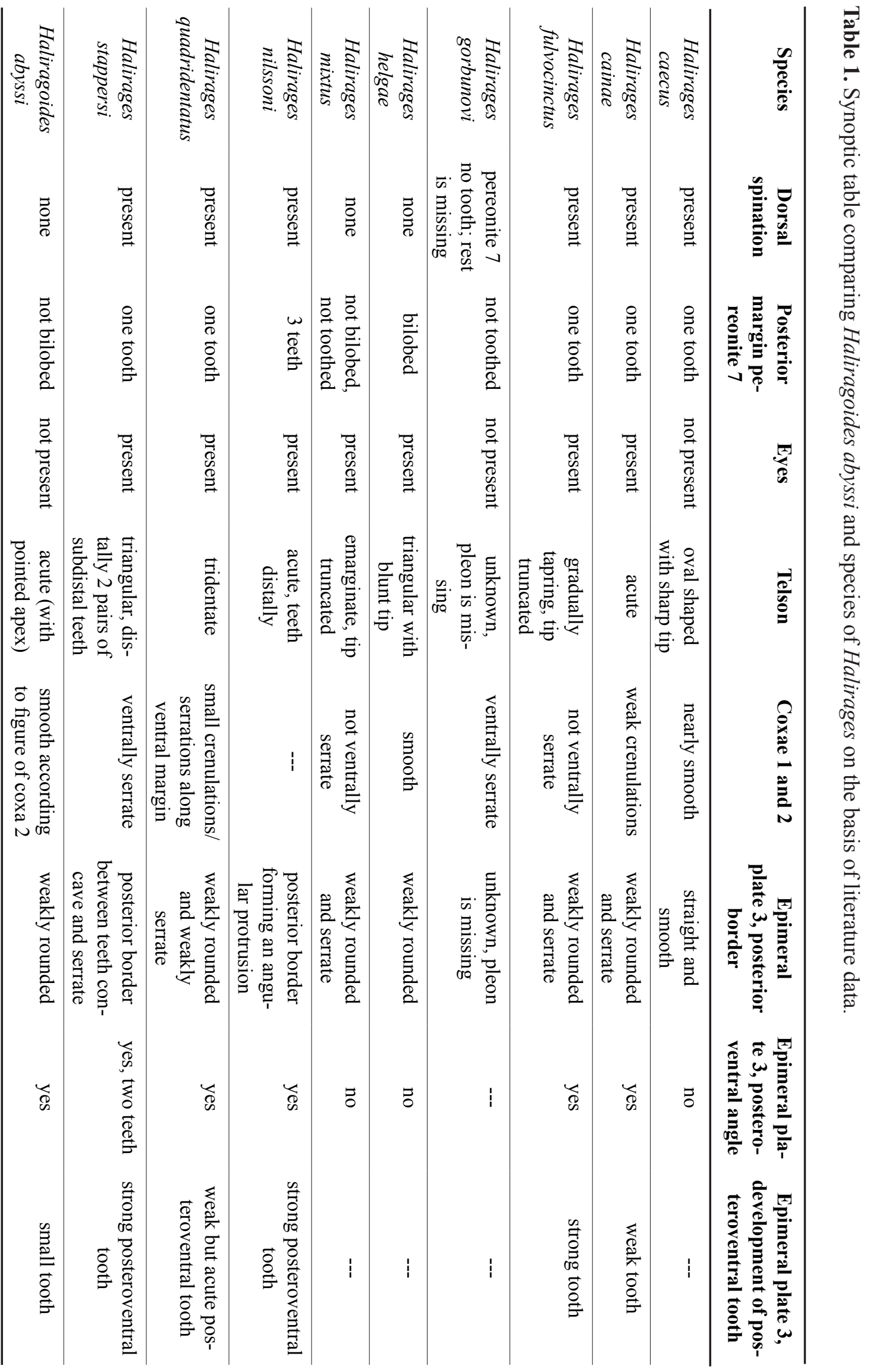


$H$. helgae sp. nov. would still differ from it by the presence of eyes, a bilobed posterior margin on pereonite 7, and a mandibular palp with article 3 half the length of article 2 (Table 1).

\section{Acknowledgements}

The Norwegian Institute of Marine Research (IMR), the Geological Survey of Norway and the Norwegian Hydrographic Service all coordinate MAREANO, this multi-disciplinary seabed mapping programme. We would like to thank Olga Lyubina (PhD, Murmansk Marine Biological Institute), Andrei Sikorski (PhD, Akvaplan-Niva as), Andrey Voronkov (PhD, IMR), and Alexander Plotkin (PhD student, University of Bergen) for translation of Russian articles, Arne Hassel (Senior Researcher, IMR) for lab assistance, and Kjell Bakkeplass (Senior Engineer, IMR) for the station map. Professor emeritus Wim Vader (Tromsø Museum) is thanked for his valuable comments on earlier versions of this manuscript.

\section{References}

Barnard J.L. \& Karaman G.S. 1991. The families and genera of Marine Gammaridean Amphipoda (except Marine Gammaroids). Records of the Australian Museum, Supplement 13: 1-866. Part 1: http:// dx.doi.org/10.3853/j.0812-7387.13.1991.91 Part 2: http://dx.doi.org/10.3853/j.0812-7387.13.1991.367

Buhl-Mortensen L., Bøe R., Dolan M.F.J., Buhl-Mortensen P., Thorsnes T., Elvenes S. \& Hodnesdal H. 2012. Banks, troughs and canyons on the continental margin off Lofoten, Vesterålen, and Troms, Norway. In: Harris P. \& Baker E. (eds) Seafloor Geomorphology as Benthic Habitat: GeoHab Atlas of Seafloor Geomorphic Features and Benthic Habitats. Elsevier Insights, London. http://dx.doi.org/10.1016/B978$\underline{0-12-385140-6.00051-7}$

Coleman C.O. 2003. "Digital inking": How to make perfect line drawings on computers. Organism Diversity \& Evolution 3, Electronic Supplement 14: 1-14.

d'Udekem d'Acoz C. 2007. The genera Haliragoides and Neohela in the North Atlantic, with the description of two new deepwater species from Norway and Svalbard (Crustacea: Amphipoda). Cahiers de Biologie Marine 48: 17-35.

d'Udekem d'Acoz C. 2012. On the genus Halirages (Crustacea, Amphipoda), with the description of two new species from Scandinavia and Arctic Europe. European Journal of Taxonomy 7: 1-32. http:// dx.doi.org/10.5852/ejt.2012.7

Gurjanova E.F. 1946. New species of Isopoda and Amphipoda from the Arctic Ocean. Transactions of the Drifting Expedition of the Main Administration of the Northern Sea Route on the Icebreaker "Sedov", 1937-1940 3:272-297 (in Russian).

Gurjanova E.F. 1951. Gammaridea of the seas of the U.S.S.R. and adjacent waters. Akademiia Nauk SSSR, Opredeliteli po Faune SSSR 41: 1-1031 (in Russian).

Kamenskaya O.E. 1980. Deep sea Amphipoda (Amphipoda, Gammaridea) collected from the drifting station "North-Pole" 22'. In: Vinogradova M.E. \& Melnikov I.A. (eds) Biology of the Central Arctic Basins. Nauk Moskva, Moscow (in Russian).

Ohlin A. 1895. Bidrag till Kännedomen om Malakostrakfaunan i Baffin Bay och Smith Sound. Akademisk Afhandling. E. Malmströms Boktryckeri, Lund, Sweden.

Sars M. 1858. Oversigt over de i den norskarctiske Region forekommende Krebsdyr. Forhandlinger $i$ Videnskabs-Selskabet i Kristiania 1858: 122-163.

Sars G.O. 1877. Prodromus descriptionis crustaceorum et pycnogonidarum, quae in Expeditione Norvegica anno 1876, observavit G.O. Sars. Archiv for Mathematik og Naturvidenskab, Kristiania (Oslo) 2: 337-371. 
RINGVOLD H. \& TANDBERG A.H.S., A new deepwater amphipod, Halirages helgae sp. nov.

Sars G.O. 1883. Oversigt af Norges Crustaceer med foreløbige Bemærkninger over de nye eller mindre bekjendte Arter. Forhandlinger i Videnskabs-Selskabet i Christiania 18: 1-124.

Stephensen K.1931. Crustacea Malacostraca VII. (Amphipoda. III). The Danish Ingolf Expedition 3: 179-290.

Weisshappel J.B. 2001. Distribution and diversity of the hyperbenthic amphipod family Calliopiidae in the different seas around the Greenland-Iceland-Faeroe-Ridge. Sarsia 86: 143-151.

Manuscript received: 4 April 2014

Manuscript accepted: 15 August 2014

Published on: 3 October 2014

Topic editor: Rudy Jocqué

Desk editor: Danny Eibye-Jacobsen

Printed versions of all papers are also deposited in the libraries of the institutes that are members of the EJT consortium: Muséum National d'Histoire Naturelle, Paris, France; Botanic Garden Meise, Belgium; Royal Museum for Central Africa, Tervuren, Belgium; Natural History Museum, London, United Kingdom; Royal Belgian Institute of Natural Sciences, Brussels, Belgium; Natural History Museum of Denmark, Copenhagen, Denmark. 